\title{
Pertimbangan Dewan Syariah Nasional Dalam Menetapkan Fatwa Akad Transaksi Syariah di Indonesia (National Sharia Council Considerations in Establishing Fatwa Sharia Transaction Agreements in Indonesia)
}

\author{
M Ridhwan Ar Rasyid ${ }^{1 *}$, Efri Syamsul Bahri ${ }^{2}$ \\ ${ }^{1}$ Sekolah Tinggi Ekonomi Islam SEBI, Indonesia, ${ }^{2}$ Sekolah Tinggi Ekonomi Islam SEBI, Indonesia
}

The National Sharia Council of the Indonesian Ula ma Council (DSN MUI) is an independent institution that plays a role in providing sharia lawyer arrangements. DSN MUI makes a fatwa to regulate the process of asset turnover in community life. DSN MUI formulates the consideration of fatwa akad sharia transaction using the concept of scientific method based on the guidance of figh scholars. This study aims to describe the consideration of DSN MUI in determining the fatwa of sharia transaction contracts. Based on this study, the consideration of fatwa akad Islamic transactions aims to benefit the people using nash qath'i approach refers to Al-Qur'an and Al-Hadist. Consideration in determining fatwas based on benefits and impacts that will occur when a fatwa is determined or not determined.

Keywords: Sharia Agreements, National Sharia Board of Indonesia, and Methods Establish Fatwa.

OPEN ACCESS

ISSN 2503-3077 (Online) (online) ISSN 2503-3077 (print)

${ }^{*}$ Correspondence: M Ridhwan Ar Rasyid

relrazed@gmail.com

Received: 21 August 2019 Accepted: 21 September 2019 Published: 30 October 2019

Citation:

Ar Rasyid MR and Syamsul Bahri E

(2019) Pertimbangan Dewan

Syariah Nasional Dalam

Menetapkan Fatwa Akad Transaksi

Syariah di Indonesia (National

Sharia Council Considerations in

Establishing Fatwa Sharia

Transaction Agreements in

Indonesia).

Perisai : Islamic Banking and

Finance Journal. 3:2.

doi: 10.21070/perisai.v3i2.2020
Dewan Syariah Nasional Majelis Ulama Indonesia (DSN MUI) merupakan lembaga independen yang berperan dalam memberikan pengaturan bermuamalah secara syariah. DSN MUI membuat fatwa untuk mengatur proses perputaran harta dalam kehidupan bermasyarakat. DSN MUI merumuskan pertimbangan fatwa akad transaksi syariah menggunakan metode ilmiah berdasarkan tuntunan ulama fiqih. Penelitian ini bertujuan untuk menggambarkan pertimbangan DSN MUI dalam menetapkan fatwa akad transaksi syariah. Hasil penelitian ini menunjukkan bahwa pertimbangan fatwa akad transaksi syariah bertujuan untuk kemaslahatan umat dengan menggunakan pendekatan nash qath'i merujuk pada Al-Qur an dan Al-Hadist. Pertimbangan dalam penetapan fatwa berdasarkan manfaat dan dampak yang akan terjadi ketika fatwa ditetapkan atau tidak ditetapkan.

Kata Kunci: Akad-akad Syariah, Dewan Syariah Nasional, dan Metode Menetapkan Fatwa 


\section{PENDAHULUAN}

Dewan Pengawas Syariah Nasional Majelis Ulama Indonesia (DSN MUI) memiliki peran dan fungsi strategis Jamal (2016) di dalam memberikan pedoman dan menjawab permasalahan kontemporer terkait produk-produk syariah khususnya pada perbankan syariah. Pedoman yang dikeluarkan DSN MUI bermanfaat dalam memberikan jaminan agar kemurnian syariah dapat berjalan dengan baik. Untuk iitu, DSN MUI mengeluarkan pedoman fatwa untuk menentukan keputusan bagaimana seharusnya suatu lembaga keuangan syariah mengambil sikap dalam menjaga kemurnian syariah.

Pada tahap selanjutnya, fatwa yang dikeluarkan oleh DSN MUI diatur dalam bentuk peraturan Bank Indonesia untuk masalah-masalah terkait muamalah di perbankan dan lembaga keuangan syariah. Salah satu contohnya adalah kontrakkontrak pengumpulan dan distribusi dana yang diatur dalam PBI No.7/46/PBI/2005. PBI ini mengatur mengenai Akad Pengumpulan dan Pembayaran untuk Menjalankan Usaha Bank yang dilakukan berdasakan Prinsip Syariah Jamal (2016).

Allah berfirman Sesungguhnya Allah menyuruh kamu menyampaikan amanat kepada yang berhak menerimanya, dan (menyuruh kamu) apabila menetapkan hukum diantara manusia supaya kamu menetapkan dengan adil. Sesungguhnya Allah memberi pengajaran yang sebaik-baiknya kepadamu. Sesungguhnya Allah adalah maha mendengar lagi maha melihat.(QS: an-nisa,58)

Keberadaan fatwa ini adalah untuk memberikan kepastian, kenyamanan bagi umat Islam dan adanya legitimasi para. Untuk itu diperlukan adanya model pertimbangan untuk menentukan kebenaran suatu fatwa. Keberadaan $\mathrm{f}$ atwa menurut Habibaty (2017) juga berfungsi untuk menerapkan secara konkret ketentuan fikih dalam masalah tertentu.

Berdasarkan uraian di atas, maka, f okus dalam penelitian ini adalah untuk mengetahui bagaimana pertimbangan penetapan fatwa-fatwa khususnya terhadap akad-akad syariah.. D engan demikian, judul penelitian ini adalah Pertimbangan Dewan Syariah Nasional dalam Menetapkan Fatwa Akad Transaksi Syariah di Indonesia.

\section{METODOLOGI}

Metode yang digunakan dalam penelitian ini adalah metode kualitatif dengan pendekatan deskriptif. Ruang lingkup $p$ enelitian ini adalah pada pembahasan akad transaksi syari ' ah meliputi: (1) pembahasan penerapan metode yang dipakai dalam penetapan fatwa terhadap akad transaksi syari ah; (2) pembahasan pertimbangan yang menjadi sebab pentingnya dewan syariah menetapkan fatwa.

\section{TINJAUAN LITERATUR}

\section{Pertimbangan}

Pertimbangan secara bahasa Arto (1998) ialah pendapat sebagai alasan terhadap suatu putusan. Pertimbangan perlu diperhatikan sebelum menetapkan fatwa, karena terdapat batasan-batasan tertentu yang menjadi syarat mutlak penetapan fatwa berdasarkan nash Al Qur'an dan Hadist untuk memahami adab-adab ketika mendiskusikan pembahasan perihal ilmu syariah dengan tujuan menetapkan suatu hukum yang nantinya menjadi landasan hukum suatu permasalahan tertentu sehingga dapat menyelesaikan dan menjawab masalah-masalah yang terjadi di masyarakat.

\section{Fatwa}

Menurut Kamus Besar Bahasa Indonesia, fatwa didefinisikan sebagai jawaban berupa keputusan atau pendapat yang diberikan oleh mufti/ahli tentang suatu masalah. Secara istilah fatwa adalah sebuah jawaban resmi terhadap: 1) pertanyaan; atau 2) persoalan penting menyangkut dogma atau hukum, yang diberikan oleh seseorang yang mempunyai otoritas untuk melakukannya (Hooker, 2003: 1) dalam Fauzi (2017) Selain itu, menurut Ahyar A.Gayo dalam Habibaty (2017) , fatwa juga berperan sebagai bentuk penegasan kembali mengenai kedudukan suatu permasalahan dalam perspektif Islam.

Istilah fatwa ialah penjelasan mujtahid berkenaan hukum syara' id al Barawi (2009). Yusuf Qardhawi memberikan pandangan baik secara bahasa maupun secara istilah. Secara bahasa, menurut Yusuf Qardhawi dalam Susamto (2016), fatwa berarti jawaban terhadap suatu kejadian. Dalam pandangan Quraisy Shihab, fatwa harus memperhatikan keadaan sosiologis umat pada saat itu sehingga tidak menimbulkan perpecahan umat atau kehancuran sebuah bangsa.

Menurut Muhammad Sa'id Muhammad al-Barawi (2009) dalam Martunis (2017), rukun fatwa ada 4 (empat). Pertama, Al-Sa'il, disebut sebagai Mustafti ialah orang yang meminta fatwa atau orang yang bertanyakan soalan-soalan yang berkaitan dengan masalah-masalah dalam agama. Kedua, AlMas'ul, disebut sebagai Mufti merupakan orang yang memberi fatwa atau orang yang menjawab semua permasalahan tersebut. Ketiga, Al 'Amaliyyah, adalah f atwa-fatwa yang dikeluarkan oleh Mufti. Keempat, Al Madhmun, merupakan kebenaran sesuatu fatwa yang terjamin.

Menurut asy-Syaikh Taqiyuddin An- Nabhani (2009) dalam Martunis (2017), jumhur ulama bersepakat untuk memberi persyaratan yang harus dipenuhi seorang mufti. Syaratsyarat tersebut mencakup syarat umum, syarat pokok, dan syarat pelengkap. Syarat umum yakni baligh, Muslim, sehat pikiran, dan cerdas. Munculnya praktik ekonomi syariah di Indonesia pada tahun 1990-an, membuat MUI menganggap perlu dibentuknya suatu badan dewan syariah yang bersifat nasional, yaitu dalam hal ini dibentuklah Dewan Syariah Nasional (DSN).

Keberadaan DSN bertujuan Yulianti (2016) untuk menangani masalah-masalah yang berhubungan dengan aktivitas lembaga keuangan syari ' ah. DSN diharapkan dapat berfungsi untuk mendorong penerapan ajaran Islam dalam kehidupan ekonomi, secara proaktif menanggapi perkembangan masyarakat Indonesia yang dinamis dalam bidang ekonomi dan keuangan. Sedangkan wewenang DSN antara lain mengeluarkan fatwa yang mengikat Dewan Pengawas Syariah di masing-masing lembaga keuangan syariah dan menjadi dasar tindakan hukum pihak terkait. Dengan demikian, o toritas fatwa tentang ekonomi syariah di Indonesia, berada dibawah DSN-MUI. 


\section{Metode Penetapan Fatwa Dewan Syariah MUI}

Sehubungan dengan penetapan hukum dalam fatwa dewan syariah Nasional MUI, maka terdapat tiga metode penetapan fatwa, yaitu: pendekatan nash qath'i dengan merujuk Al-qur ' an dan Al-hadist, pendekatan qauli dengan merujuk kitabkitab fiqih dengan melihat kecocokan hukum yang sudah ditetapkan oleh para ulama fiqih, dan pendekatan manhaji dengan beberapa metode kajian terdiri dari tiga metode penetapan fatwa yang dapat dirujuk dengan penjelasan sebagai berikut.

Metode Bayani (Kajian Semantik ). Dalam metode pertama dimasukkan semua kegiatan yang berkaitan dengan kajian kebahasaan (semantik) yaitu: kapan suatu lafal diartikan secara majaz bagaimana memilih salah satu dari lafal musytarak ( ambiguitas ), mana ayat yang umum dan mana pula yang khusus mana ayat yang qath'i (yang artinya tidak dapat berubah) serta mana pula yang dzhanni, kapan suatu suatu perintah dianggap perkara wajib dan kapan pula dianggap perkara sunnah, kapan larangan itu haram dan kapan pula dihukumi makruh dan seterusnya.

Metode Qiyasi (Kajian Ta'lili ). Dalam metode kedua dimasukan semua penalaran yang menjadikan 'illat (keadaan atau sifat yang menjadi tambatan hukum) sebagai titik tolaknya, kajian ini merupakan pembahasan tentang cara-cara menemukan 'illat, penggunaan 'illat dalam qiyas dan istihsan serta pengubahan hukum itu sendiri sekiranya ditemukan 'illat baru (sebagai pengganti yang lama).

Metode istilahi (kajian pertimbangan kemaslahatan berdasarkan nash umum). Dalam metode ketiga mengidentifikasi masalah-masalah yang tidak mempunyai nash khusus sebagai rujukan, dalam kajian ini ayat-ayat umum dikumpulkan guna menciptakan beberapa perinsip umum, yang di gunakan untuk melindungi atau mendatangkan kemaslahatan tertentu, prinsip-prinsip tersebut disusun menjadi tiga tingkatan Yulianti (2016), yaitu: dharuriyat, hajiyat dan tahsiniyat.

Dharuriyat, kebutuhan esensial. Merupakan maslahat yang bersifat penting dimana kehidupan manusia sangat tergantung padanya, baik aspek diniyah (agama) maupun aspek duniawi, sehingga tidak dapat ditinggalkan dalam kehidupan manusia, maka ini merupakan suatu pokok yang harus diprtimbangkan dalam menetapkan hukum islam dengan tujuan menjaga kehidupan di dunia dan akhirat.

Hajiyat, kebutuhan sekunder. Merupakan maslahat yang diperlukan untuk mempermudah dalam kehidupan dan menghilangkan kesuliatan maupun kesempitan. Tahsiniyat, kebutuhan kemewahan. Merupakan tuntutan muru'ah (moral), yang dimaksudkan untuk kebaikan dan meningkatkan kualitas kehidupan manusia Shidiq (2009).

[Figure 1 about here.]

Namun di dalam praktiknya pola ta'lili di gunakan apabila ada perasaan tidak puas dengan pola bayani, memungkinkan untuk memperkuat argumen atau untuk mengalihkan kepada kesimpulan lain agar terasa lebih logis dan lebih berhasil sehingga pola istilahi ini digunakan sesuai keadaannya dan tidak menggunakan dalil khusus bila ada persoalan-persoalan baru yang biasanya muncul karena penggunaan teknologi dan kemajuan ilmu pengetahuan.
Sesungguhnya ketiga metode ijtihad bayani, ta'lili atau istilahi tersebut berkaitan dengan tasyri' sehingga bertujuan sebagai maslahat yang merupakan pola dalam rangka memahami tujuan penetapan hukum islam, yaitu kemaslahatan hidup dan kehidupan manusia, terutama dalam bidang muamalah dan ketiga pola ini dapat diterapkan secara bersamaan yaitu memahami nash, menelusuri ' illat nash dan memikirkan secara mendalam tentang kemaslahatan yang merupakan tujuan dari penetapan hukum islam.

Berhubungan dengan rekayasa sosial yang erat kaitanya dengan teknologi dan kemajuan ilmu pengetahuan sekarang ini menimbulkan persoalan baru yang berdampak pada perubahan gaya hidup lebih modern sehingga timbul persoalan utama dalam menetapkan hukum islam dan merealisasikanya dengan demikian maka dirasa penting menentukan kualitas pemahaman dan penguasaan terhadap Al qur'an, Hadist, usul fiqh dan bahasa arab serta memahami suatu ilmu sampai tingkatan tertentu s eperti: ilmu antropologi, sosiologi, ekonomi modern.

\section{Akad dalam Islam}

Perjanjian atau kontrak dalam istilah hukum Islam disebut dengan "akad", yang berarti ikatan dan tali pengikat, secara etimologi, akad berarti ikatan antara dua perkara, baik ikatan secara nyata maupun ikatan secara maknawi dilihat dari beberapa aspek yang mendasarinya. Semua perikatan yang dilakukan oleh dua pihak lebih tidak boleh menyimpang dan harus sejalan dengan kehendak syari ' at sehingga tidak ada kesepakatan yang bertujuan menipu orang lain, bertransaksi barang-barang yang diharamkan dan kesempatan untuk berbuat dzalim terhadap orang lain, dalam terminology ulama ahli fiqih akad dapat ditinjau dari dua sisi yakni: b ahasa dan istilah.

Pengertian akad dalam arti luas hampir sama dengan akad dari segi bahasa menurut pendapat ulama syafi 'iyyah, malikiyah dan hanafiah yaitu segala sesuatu yang dikerjakan oleh seseorang berdasarkan keinginanya sendiri seperti wakaf, talak, pembebasan atau sesuatu yang pembentuknya membutuhkan keinginan dua orang seperti jual-beli, perwakilan dan gadai.

Menurut Ali Atabik dan Ahmad Zuhdi Muhdlor dalam Arifin (2014) kata akad mempunya arti: mengikat, menyimpulkan, menggabungkan, bisa juga berarti: persepakatan, perjanjian dan kontrak). Sedangkan, menurut Ascarya (2006), jenis akad yang terkait dengan unit usaha syariah seperti perbankan syariah dan lembaga keuangan syariah sedikitnya terdapat 11 (sebelas) akad transaksi antara lain: akad murabahah, akad murabahah, akad istishna, akad mudharabah, akad musyarakah, akad ijarah, akad wakalah, akad kafalah, akad hawalah, akad rahn dan akad qard.

Akad murabahah adalah suatu bentuk jual beli tertentu ketika penjual menyatakan biaya perolehan barang, meliputi harga barang dan biaya biaya lain yang dikeluarkan untuk memperoleh barang tersebut dengan tingkat keuntungan (margin) yang diinginkan, dan tingkat keuntungan ini bisa dalam bentuk lumpsum atau persentase dari biaya perolehan. Akad Salam Merupakan bentuk jual beli dengan pembayaran dimuka dan penyerahan barang di kemudian hari (advanced payment or forwad buying or future sales) dengan harga, spe- 
sifikasi, jumlah, kualitas, tanggal, dan tempat penyerahan yang jelas, serta disepakati sebelumnya dalam perjanjian.

Akad istishna' adalah pemesanan kepada perusahaan untuk memproduksi barang atau komoditas tertentu untuk pembeli/pemesan, istishna merupakan salah satu bentuk jual beli dengan pemesanan yang mirip dengan salam yang merupakan bentuk jual beli kedua yang di perbolehkan syariah, jika perusahaan memproduksi barang yang dipesan dengan bahan baku dari perusahaan maka akad istishna itu berlaku, agar akad istishna menjadi sah harga harus ditetapkan diawal sesuai dengan kesepakatan dan barang harus memiliki spesifikasi yang jelas dan sudah di sepakati bersama dalam akad istishna pembayaran dapat dilakukan diawal, dicicil sampai selesai atau dibelakang dengan demikian akad istishna biasanya diaplikasikan untuk industry dan barang manufaktur.

Akad mudharabah merupakan bentuk penanaman modal kepada orang yang berniaga sehingga dia mendapatkan persentase keuntungan sehingga mudharabah merupakan bentuk kontrak transaksi bagi hasil ketika pemilik modal/dana (pemodal) biasa di sebut dengan shahibul maal/rabbul maal, menyediakan modal (100 persen) kepada pengusaha sebagai pengelola biasa di sebut sebagai mudharib untuk melakukan aktivitas produktif dengan syarat bahwa keuntungan yang dihasilkan akan dibagi menurut kesepakatan yang di tentukan sebelumnya dalam akad (yang besarnya juga dipengaruhi oleh kekuatan pasar) shahibul maal (pemodal) adalah pihak yang memiliki modal, tetapi tidak bisa berbisnis dan mudharib (pengelola atau entrepreneur) adalah pihak yang pandai berbisnis, tetapi tidak memiliki modal.

Akad musyarakah merupakan akad bagi hasil ketika dua atau lebih pengusaha pemilik dana/modal bekerja sama dengan mitra usaha, membiayai investasi usaha baru atau yang sudah berjalan, mitra usaha pemilik modal berhak ikut serta dalam manajemen perusahaan, tetapi itu bukan merupakan keharusan sehingga para pihak dapat membagi pekerjaan mengelola usaha sesuai kesepakatan dan mereka juga dapat meminta gaji/upah untuk tenaga dan keahlian yang mereka curahkan untuk usaha tersebut.

Akad ijarah merupakan salah satu teknik pembiayaan ketika kebutuhan pembiayaan investor untuk membeli asset terpenuhi dan investor hanya membayar sewa pemakaian tanpa harus mengeluarkan modal yang cukup besar untuk asset tersebut. Akad wakalah. Merupakan pelimpahan kekuasaan oleh satu pihak (muwakil) kepada pihak lain (wakil) dalam hal-hal yang boleh diwakilkan kemudian atas jasanya maka penerima kekuasaan dapat menerima imbalan tertentu dari pemberi amanah.

Akad kafalah merupakan jaminan, beban, atau tanggungan yang diberikan oleh penanggung (kafil) kepada pihak ketiga untuk memenuhi kewajiban pihak kedua atau yang ditanggung (makful), kafalah dapat juga berarti mengalihkan tanggung jawab seseorang yang dijamin dengan berpegang pada tanggung jawab orang lain sebagai penjamin kemudian atas jasanya maka penjamin dapat meminta imbalan tertentu dari orang yang dijamin.

Akad hawalah m erupakan pengalihan hutang/ piutang dari orang yang berhutang/ berpiutang kepada orang lain yang wajib menanggungnya atau menerimanya. Akad rahn m erupakan pelimpahan kekuasaan oleh satu pihak kepada pihak lain dalam hal-hal yang boleh diwakilkan kemudian atas jasanya maka penerima kekuasaan dapat menerima imbalan tertentu dari pemberi amanah.

Akad qard m erupakan pinjaman kebajikan atau pinjaman lunak tanpa imbalan, biasanya digunakan untuk pembelian barang-barang fungible (yaitu barang yang dapat diperkirakan dan diganti sesuai berat, ukuran dan jumlahnya) pinjaman ini bersifat murni tanpa imbalan bunga ketika peminjam telah mendapatkan uang tunai dari pemilik dana kemudian pengembalianya hanya wajib mengembalikan pokok hutangnya saja pada waktu tertentu dimasa yang akan datang peminjam boleh mengembalikan lebih besar sebagai ucapan terimakasih namun dilakukan atas prakarsa sendiri dan tidak boleh disepakati jumlahnya diawal akad.

\section{Penelitian Terdahulu}

[Table 1 about here.]

\section{HASIL PENELITIAN DAN PEMBAHASAN}

Studi pembahasan tentang pertimbangan yang diambil DSN MUI dalam penetapan fatwa terkait akad transaksi syariah dan penerapan konsep penetapan fatwa dengan menggunakan konsep pendekatan nash qath'i, pendekatan qauli, pendekatan manhaji. penulis hanya membahas sebelas akad transaksi syariah karena kesebelas akad tersebut merupakan akad yang paling sering dipakai dalam kegiatan industri keuangan syariah untuk mengGambarkan bagaimana pertimbangan dan penerapan konsep DSN MUI dalam menentukan dan menetapkan fatwa terhadap akad transaksi syariah.

Berikut ini merupakan tabel fatwa sebelas transaksi syariah yang akan dibahas.

\section{[Table 2 about here.]}

(Sumber : Kumpulan fatwa DSN-MUI)

\section{Akad Murabahah}

Penetapan fatwa terhadap Akad transaksi murabahah dengan merujuk kepada fatwa dewan syariah DSN-MUI dapat diketahui kejelasanya secara hukum dengan melalui konsep pendekatan nash Qath'i yang merujuk kepada Al-qur'an dan AlHadist diantara ayat dan hadist yang menjadi sumber hukum penetapan fatwa akad murabahah yang terdapat dalam (fatwa DSN-MUI no 04/DSN-MUI/IV/2000) disebutkan bahwa yang menjadi landasan sumber hukum akad transaksi murabahah terdapat didalam Qur'an surat Al-Baqarah ayat 280, dan Hadist Nabi Salallahu'alaihi wasalam riwayat Ibnu majah dari Shuhaib kemudian pertimbangan yang diambil DSN-MUI dalam menetapkan fatwa akad transaksi murabahah terdapat dalam (fatwa DSN-MUI no 04/DSN-MUI/IV/2000) yaitu:

- Masyarakat banyak memerlukan bantuan penyaluran dana dari bank berdasarkan pada prinsip jual beli.

- Bahwa dalam rangka membantu masyarakat guna melangsungkan dan meningkatkan kesejahteraan dalam berbagai kegiatan, bank syari’ah perlu memiliki fasilitas murabahah bagi yang memerlukannya, yaitu menjual suatu barang dengan menegaskan harga belinya kepada pembeli dan pembeli membayarnya dengan harga yang lebih sebagai laba. 
- Bahwa oleh karena itu, DSN memandang perlu menetapkan fatwa tentang Murabahah untuk dijadikan pedoman oleh bank syari'ah.

Dengan melihat pernyataan di atas membuktikan bahwa pertimbangan yang diambil oleh DSN-MUI merupakan pertimbangan yang bertujuan untuk kemaslahatan umat manusia dengan kemudahan dalam berteransaksi jual-beli dengan cara memberikan harga lebih sebagai margin diawal akad, banyak orang menganggap akad murabahah dibank syariah sama saja dengan kredit bunga di bank konvensional, karena samasama memberikan harga lebih dari harga dipasaran dampak inilah yang muncul menjadi kesalahpahaman dimasyarakat oleh karena itu DSN-MUI mengeluarkan fatwa untuk menjelaskan kebolehan akad transaksi murabahah diberlakukan dalam jual-beli secara sah dengan konsep yang jauh berbeda dengan sistem bunga di perbankan konvensional.

\section{Akad Salam}

Penetapan fatwa terhadap Akad transaksi salam dengan merujuk kepada fatwa dewan syariah DSN-MUI dapat diketahui kejelasanya secara hukum dengan melalui konsep pendekatan nash Qath'i yang merujuk kepada Al-qur'an dan Al-Hadist diantara ayat dan hadist yang menjadi sumber hukum penetapan fatwa akad salam yang terdapat dalam (fatwa DSNMUI no 05/DSN-MUI/IV/2000) disebutkan bahwa yang menjadi landasan sumber hukum akad salam terdapat didalam Qur'an surat Al-Baqarah ayat 282, dan Hadist Nabi Salallahu'alaihi wasalam riwayat Bukhari, Sahih al-Bukhari [Beirut: Dar al-Fikr, 1955], jilid 2, hlm 36, kemudian pertimbangan yang diambil DSN-MUI dalam menetapkan fatwa akad transaksi salam terdapat dalam (fatwa DSN-MUI No. 05/DSNMUI/IV/2000) yaitu:

- Bahwa jual beli barang dengan cara pemesanan dan pembayaran harga lebih dahulu dengan syarat-syarat tertentu, disebut dengan salam, kini telah melibatkan pihak perbankan.

- Bahwa agar cara tersebut dilakukan sesuai dengan ajaran Islam, DSN memandang perlu menetapkan fatwa tentang salam untuk dijadikan pedoman oleh lembaga keuangan syari ah.

Sejatinya akad transaksi salam dipergunakan dalam kegiatan transaksi pemesanan yaitu pembeli memesan suatu komoditi dengan pembayaran diawal dan penjual menjelaskan spesifikasi komoditi yang akan dijual sehingga manfaat yang didapat oleh penjual berupa modal sebagai dana untuk menyiapkan komoditi tersebut dalam tempo yang sudah ditentukan diawal, kemudian ketika penjual menyerahkan barang lalu didapati rusak maka pembeli di perbolehkan memilih atau menolaknya namun sebagian masyarakat beranggapan bahwa transaksi akad salam mirip dengan transaksi ijon pada pertanian yang memesan hasil pertanian sebelum ditanam dan pemesan tidak boleh menolak atau memilih hasil pertanian jika hasilnya rusak dan tidak sesuai spesifikasi yang dijelaskan penjual dengan pertimbangan dampak masalah yang akan terjadi maka DSN-MUI mengeluarkan fatwa akad transaksi salam sebagai pedoman melakukan transaksi salam dengan benar.

\section{Akad Istishna'}

Penetapan fatwa terhadap Akad transaksi istishna ' dengan merujuk kepada fatwa dewan syariah DSN-MUI dapat diketahui kejelasanya secara hukum dengan melalui konsep pendekatan nash Qath'i yang merujuk kepada Al-qur'an dan AlHadist diantara ayat dan hadist yang menjadi sumber hukum penetapan fatwa akad istishna' yang terdapat dalam (fatwa DSN-MUI No. 06/DSN-MUI/IV/2000) disebutkan bahwa yang menjadi landasan sumber hukum akad istishna' terdapat didalam Hadist Nabi Salallahu'alaihi wasalam riwayat Tirmizi dari 'Amr bin 'Auf kemudian pertimbangan yang diambil DSN-MUI dalam menetapkan fatwa akad transaksi istishna' terdapat dalam (fatwa DSN-MUI No. 06/DSN-MUI/IV/2000) yaitu:

- Bahwa kebutuhan masyarakat untuk memperoleh sesuatu, sering memerlukan pihak lain untuk membuatkannya, dan hal seperti itu dapat dilakukan melalui jual beli istishna'

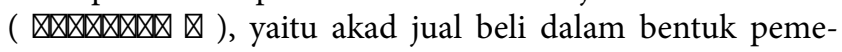
sanan pembuatan barang tertentu dengan kriteria dan persyaratan tertentu yang disepakati antara pemesan (pembeli, mustashni') dan penjual (pembuat, shani')

- Bahwa transaksi istishna' pada saat ini telah dipraktekkan oleh lembaga keuangan syari'ah.

- Bahwa agar praktek tersebut sesuai dengan syari ' ah Islam, DSN memandang perlu menetapkan fatwa tentang istishna' untuk menjadi pedoman.

Sama halnya dengan akad transaksi salam akad transaksi istishna merupakan akad jual-beli barang dengan melakukan pemesanan terlebih dahulu akan tetapi sedikit berbeda pada saat pembayaranya akad istishna 'dilakukan pembayaran ketika barang yang dipesan sudah diterima namun diperbolehkan juga pembayaran dilakukan diawal akad namun sebenarnya transaksi akad jual beli salam tidak memenuhi salah satu rukun akad yaitu keberadaan barang yang belum dimiliki oleh penjual akan tetapi akad transaksi salam dilakukan atas dasar saling ridha dengan kesepakatan antara penjual dan pembeli maka dengan pertimbangan manfaat DSN-MUI mengeluarkan fatwa sebagai pedoman landasan hukum.

\section{Akad Mudharabah}

Penetapan fatwa terhadap Akad transaksi mudharabah dengan merujuk kepada fatwa dewan syariah DSN-MUI dapat diketahui kejelasanya secara hukum dengan melalui konsep pendekatan nash Qath'i yang merujuk kepada Al- Q ur'an dan Al-Hadist diantara ayat dan hadist yang menjadi sumber hukum penetapan fatwa akad mudharabah yang terdapat dalam (fatwa DSN-MUI No. 07/DSN-MUI/IV/2000) disebutkan bahwa yang menjadi landasan sumber hukum akad mudharabah terdapat didalam Qur'an surat an-nisa ayat 29 dan Hadist Nabi Salallahu'alaihi wasalam riwayat Thabrani dari Ibnu abbas kemudian pertimbangan yang diambil DSN-MUI dalam menetapkan fatwa akad transaksi mudharabah terdapat dalam (fatwa DSN-MUI No. 07/DSN-MUI/IV/2000) yaitu:

- Bahwa dalam rangka mengembangkan dan meningkatkan dana lembaga keuangan syari ' ah (LKS), pihak LKS dapat menyalurkan dananya kepada pihak lain dengan cara mudharabah, yaitu akad kerjasama suatu usaha antara dua pihak 
di mana pihak pertama (malik, shahib al-mal, LKS) menyediakan seluruh modal, sedang pihak kedua ('amil, mudharib, nasabah) bertindak selaku pengelola, dan keuntungan usaha dibagi di antara mereka sesuai kesepakatan yang dituangkan dalam kontrak.

- Bahwa agar cara tersebut dilakukan sesuai dengan syari ' ah Islam, DSN memandang perlu menetapkan fatwa tentang mudharabah untuk dijadikan pedoman oleh LKS.

Sedikit sekali peminat berteransaksi akad mudharabah dikarenakan resiko yang lebih besar akan diproleh pemilik modal karena akad mudharabah merupakan suatu akad kontrak kerjasama antara pemilik dana/modal dengan pemilik usaha dengan persentase bagi hasil keuntungan lebih besar diberikan kepada pemilik modal, resiko yang timbul dari akad mudharabah berupa penipuan dari pemilik usaha yang tidak melengkapai data pribadinya secara lengkap sehingga berdampak terhadap tingkat kepercayaan masyarakat dalam berinvestasi secara aman menggunakan akad mudharabah dengan demikian DSN-MUI mempertimbangkan pentingnya mengeluarkan sebuah keputusan berupa fatwa yang disertai dengan peraturan-peraturan untuk menghindari resiko ketika akad mudharabah diberlakukan.

\section{Akad Musyarakah}

Penetapan fatwa terhadap Akad transaksi musyarakah dengan merujuk kepada fatwa dewan syariah DSN-MUI dapat diketahui kejelasanya secara hukum dengan melalui konsep pendekatan nash Qath'i yang merujuk kepada Al-qur'an dan Al-Hadist diantara ayat dan hadist yang menjadi sumber hukum penetapan fatwa akad musyarakah yang terdapat dalam (fatwa DSN-MUI No. 08/DSN-MUI/IV/2000) disebutkan bahwa yang menjadi landasan sumber hukum akad musyarakah terdapat didalam Qur'an surat ash-shad ayat 24 dan Hadist Nabi Salallahu'alaihi wasalam riwayat Abu Daud, yang dishahihkan oleh al-Hakim, dari Abu Hurairah kemudian pertimbangan yang diambil DSN-MUI dalam menetapkan fatwa akad transaksi musyarakah terdapat dalam (fatwa DSN-MUI No. 08/DSN-MUI/IV/2000) yaitu:

- Bahwa kebutuhan masyarakat untuk meningkatkan kesejahteraan dan usaha terkadang memerlukan dana dari pihak lain, antara lain melalui pembiayaan musyarakah, yaitu pembiayaan berdasarkan akad kerjasama antara dua pihak atau lebih untuk suatu usaha tertentu, di mana masing-masing pihak memberikan kontribusi dana dengan ketentuan bahwa keuntungan dan resiko akan ditanggung bersama sesuai dengan kesepakatan;

- Bahwa pembiayaan musyarakah yang memiliki keunggulan dalam kebersamaan dan keadilan, baik dalam berbagi keuntungan maupun resiko kerugian, kini telah dilakukan oleh lembaga keuangan syari'ah (LKS);

- Bahwa agar cara tersebut dilakukan sesuai dengan prinsipprinsip syariah Islam, DSN memandang perlu menetapkan fatwa tentang musyarakah untuk dijadikan pedoman oleh LKS.

Sebenarnya akad transaksi musyarakah merupakan akad investasi yang dapat membantu orang lain membagun usaha dengan cara masing masing pihak menyerahkan dana kemudian resiko dan keuntungan ditanggung bersama sesuai persentase kontribusi dana masing-masing pihak, pertimbangan DSN-MUI juga mengambil asas keadilan dan kerjasama dalam mengembangkan ekonomi untuk menjaga keberlangsungan kegiatan akad transaksi musyarakah maka DSN_MUI mengeluarkan fatwa sebagai pedoman pelaksanaan akad musyarakah.

\section{Akad ljarah}

Penetapan fatwa terhadap Akad ijarah dengan merujuk kepada fatwa dewan syariah DSN-MUI dapat diketahui kejelasanya secara hukum dengan melalui konsep pendekatan nash Qath'i yang merujuk kepada Al-qur'an dan Al-Hadist diantara ayat dan hadist yang menjadi sumber hukum penetapan fatwa akad ijarah yang terdapat dalam (fatwa DSN-MUI No. 09/DSNMUI/IV/2000) disebutkan bahwa yang menjadi landasan sumber hukum akad ijarah terdapat didalam Qur'an surat alqashas ayat 26 dan Hadist Nabi Salallahu'alaihi wasalam riwayat 'Abd Ar-razzaq dari Abu Hurairah dan Abu Sa'id al-khudri, kemudian pertimbangan yang diambil DSN-MUI dalam menetapkan fatwa akad transaksi ijarah terdapat dalam (fatwa DSN-MUI No. 09/DSN-MUI/IV/2000) yaitu:

- Bahwa kebutuhan masyarakat untuk memperoleh manfaat suatu barang sering memerlukan pihak lain melalui akad ijarah, yaitu akad pemindahan hak guna (manfaat) atas suatu barang dalam waktu tertentu dengan pembayaran sewa (ujrah), tanpa diikuti dengan pemindahan kepemilikan barang itu sendiri.

- Bahwa kebutuhan masyarakat untuk memperoleh jasa pihak lain guna melakukan pekerjaan tertentu melalui akad ijarah dengan pembayaran upah (ujrah/fee).

- Bahwa kebutuhan akan ijarah kini dapat dilayani oleh lembaga keuangan syariah (LKS) melalui akad pembiayaan ijarah.

- Bahwa agar akad tersebut sesuai dengan ajaran Islam, DSN memandang perlu menetapkan fatwa tentang akad ijarah untuk dijadikan pedoman oleh LKS.

Akad ijarah merupakan akad yang digunakan bagi penyedia jasa atau barang yang dapat disewakan pada saat ini akad ijarah merupakan akad yang sering digunakan oleh masyarakat untuk memenuhi kebutuhan terhadap suatu barang tanpa harus membeli barang tersebut dan keuntungan bagi pemberi jasa atau sewa berupa ujrah yang dibayarkan pihak penyewa, pertimbangan DSN-MUI diatas merupakan alasan yang mendasar dalam menetapkan fatwa akad transaksi ijarah.

\section{Akad Wakalah}

Penetapan fatwa terhadap Akad wakalah dengan merujuk kepada fatwa dewan syariah DSN-MUI dapat diketahui kejelasanya secara hukum dengan melalui konsep pendekatan nash Qath'i yang merujuk kepada Al-qur'an dan Al-Hadist diantara ayat dan hadist yang menjadi sumber hukum penetapan fatwa akad wakalah yang terdapat dalam (fatwa DSNMUI no 10/DSN-MUI/IV/2000) disebutkan bahwa yang menjadi landasan sumber hukum akad wakalah terdapat didalam Qur'an surat al- kahfi ayat 19 dan Hadist Nabi Salallahu'alaihi wasalam riwayat Bukhari dari Abu Hurairah, kemudian pertimbangan yang diambil DSN-MUI dalam menetapkan fatwa 
akad transaksi wakalah terdapat dalam (fatwa DSN-MUI no 10/DSN-MUI/IV/2000) yaitu:

- Bahwa dalam rangka mencapai suatu tujuan sering diperlukan pihak lain untuk mewakilinya melalui akad wakalah, yaitu pelimpahan kekuasaan oleh satu pihak kepada pihak lain dalam hal-hal yang boleh diwakilkan.

- Bahwa praktek wakalah pada LKS dilakukan sebagai salah satu bentuk pelayanan jasa perbankan kepada nasabah.

- Bahwa agar praktek wakalah tersebut dilakukan sesuai dengan ajaran Islam, DSN memandang perlu menetapkan fatwa tentang wakalah untuk dijadikan pedoman oleh LKS.

Akad wakalah sering dipergunakan diindustri perbankan sperti transfer uang akad wakalah begitu penting ditengah pesatnya ekonomi saat ini yang memerlukan aktivitas transaksi yang cepat sehingga diperlukan pihak-pihak yang bertanggung jawab sehingga DSN-MUI mengeluarkan pedoman akad wakalah untuk memudahkan transaksi dengan berlandaskan hukum islam.

\section{Akad Kafalah}

Penetapan fatwa terhadap Akad kafalah dengan merujuk kepada fatwa dewan syariah DSN-MUI dapat diketahui kejelasanya secara hukum dengan melalui konsep pendekatan nash Qath ' i yang merujuk kepada Al-qur' an dan Al-Hadist diantara ayat dan hadist yang menjadi sumber hukum penetapan fatwa akad kafalah yang terdapat dalam (fatwa DSN-MUI No. 11/DSN-MUI/IV/2000) disebutkan bahwa yang menjadi landasan sumber hukum akad kafalah terdapat didalam Qur' an surat al- maidah ayat 2 dan Hadist Nabi Salallahu ' alaihi wasalam riwayat Bukhari dari Salamah bin Akwa '. kemudian pertimbangan yang diambil DSN-MUI dalam menetapkan fatwa akad transaksi kafalah terdapat dalam (fatwa DSNMUI No. 11/DSN-MUI/IV/2000) yaitu:

- Bahwa dalam rangka menjalankan usahanya, seseorang sering memerlukan penjaminan dari pihak lain melalui akad kafalah, yaitu jaminan yang diberikan oleh penanggung (kafiil) kepada pihak ketiga untuk memenuhi kewajiban pihak kedua atau yang ditanggung (makfuul 'anhu, ashil).

- Bahwa untuk memenuhi kebutuhan usaha tersebut, Lembaga Keuangan Syariah (LKS) berkewajiban untuk menyediakan satu skema penjaminan (kafalah) yang berdasarkan prinsipprinsip syar'iah.

- Bahwa agar kegiatan kafalah tersebut dilakukan sesuai dengan ajaran Islam, DSN memandang perlu menetapkan fatwa tentang kafalah untuk dijadikan pedoman oleh LKS.

Akad kafalah merupakan akad jaminan yang dapat dilakukan dengan tujuan mempermudah orang lain dalam bentuk penjamin tanggung jawab, dengan melihat pertimbangan DSNMUI diatas kita dapat mngerti mengapa akad kafalah penting untuk ditetapkan dalam sebuah fatwa.

\section{Akad Hawalah}

Penetapan fatwa terhadap Akad hawalah dengan merujuk kepada fatwa dewan syariah DSN-MUI dapat diketahui kejelasanya secara hukum dengan melalui konsep pendekatan nash Qath ' i yang merujuk kepada Al-qur' an dan Al-Hadist diantara ayat dan hadist yang menjadi sumber hukum penetapan fatwa akad hawalah yang terdapat dalam (fatwa DSNMUI no 12/DSN-MUI/IV/2000) disebutkan bahwa yang menjadi landasan sumber hukum akad hawalah terdapat didalam Hadist Nabi Salallahu' alaihi wasalam riwayat Bukhari dari Abu Hurairah. kemudian pertimbangan yang diambil DSNMUI dalam menetapkan fatwa akad transaksi hawalah terdapat dalam (fatwa DSN-MUI no 12/DSN-MUI/IV/2000) yaitu:

- Bahwa terkadang seseorang tidak dapat membayar utangutangnya secara langsung karena itu, ia boleh memindahkan penagihannya kepada pihak lain, yang dalam hukum Islam disebut dengan hawalah, yaitu akad pengalihan utang dari satu pihak yang berutang kepada pihak lain yang wajib menanggung /membayarnya.

- Bahwa akad hawalah saat ini bisa dilakukan oleh LKS.

- Bahwa agar cara tersebut dilakukan sesuai dengan ajaran Islam, DSN memandang perlu menetapkan fatwa tentang hawalah untuk dijadikan pedoman oleh LKS.

Dengan pertimbangan DSN-MUI diatas dapat kita ketahui akad hawalah merupakan akad pengalihan hutang untuk menolong orang lain demi kemaslahatan bersama agar tidak terjadi konflik yang berkepanjanga serta dampak buruk yang akan terjadi ketika hutang di tunda-tunda maka dengan pertimbangan diatas DSN-MUI mengeluarkan fatwa dengan tujuan memberikan pedoman kemudahan dimasyarakat untuk meringankan beban terkait hutang.

\section{Akad Rahn}

Penetapan fatwa terhadap Akad rahn dengan merujuk kepada fatwa dewan syariah DSN-MUI dapat diketahui kejelasanya secara hukum dengan melalui konsep pendekatan nash Qath ' i yang merujuk kepada Al-qur' an dan Al-Hadist diantara ayat dan hadist yang menjadi sumber hukum penetapan fatwa akad rahn yang terdapat dalam (fatwa DSN-MUI No. 25/DSNMUI/IV/2002) disebutkan bahwa yang menjadi landasan sumber hukum akad rahn terdapat didalam Hadist Nabi Salallahu ' alaihi wasalam riwayat Bukhari dari Abu Hurairah. kemudian pertimbangan yang diambil DSN-MUI dalam menetapkan fatwa akad transaksi rahn terdapat dalam (fatwa DSN-MU I No. 25/DSN-MUI/IV/2002) yaitu:

- Bahwa salah satu bentuk jasa pelayanan keuangan yang menjadi kebutuhan masyarakat adalah pinjaman dengan menggadaikan barang sebagai jaminan utang.

- Bahwa lembaga keuangan syariah (LKS) perlu merespon kebutuhan masyarakat tersebut dalam berbagai produknya.

- Bahwa agar cara tersebut dilakukan sesuai dengan prinsipprinsip syariah, Dewan Syariah Nasional memandang perlu menetapkan fatwa untuk dijadikan pedoman tentang Rahn, yaitu menahan barang sebagai jaminan atas utang.

Akad rahn sangat memebantu dalam mendapatkan dana pinjaman dengan cepat karena akad rahn dilakukan dengan menggadaikan barang yang berharga sebagai jaminan peminjaman hutang dengan pertimbangan diatas DSN-MUI mengeluarkan fatwa sebagai pedoman keberlangsungan akad rahn untuk merespon tingkat produktivitas masyarakat. 


\section{Akad Qard}

Penetapan fatwa terhadap Akad qard dengan merujuk kepada fatwa dewan syariah DSN-MUI dapat diketahui kejelasanya secara hukum dengan melalui konsep pendekatan nash Qath ' i yang merujuk kepada Al-qur' an dan Al-Hadist diantara ayat dan hadist yang menjadi sumber hukum penetapan fatwa akad qard yang terdapat dalam (fatwa DSN-MUI No.19/DSNMUI/IV/2001) disebutkan bahwa yang menjadi landasan sumber hukum akad qard terdapat didalam Hadist Nabi Salallahu ' alaihi wasalam riwayat Bukhari dari Abu Hurairah.

Pertimbangan yang diambil DSN-MUI dalam menetapkan fatwa akad transaksi qard terdapat dalam (fatwa DSN-MUI No.19/DSN-MUI/IV/2001) yaitu:

- Bahwa Lembaga Keuangan Syariah (LKS) disamping sebagai lembaga komersial, harus dapat berperan sebagai lembaga social yang dapat meningkatkan perekonomian secara maksimal.

- Bahwa salah satu sarana peningkatan perekonomian yang dapat dilakukan oleh LKS adalah penyaluran dana melalui prinsip al-Qardh, yakni suatu akad pinjaman kepada nasabah dengan ketentuan bahwa nasabah wajib mengembalikan dana yang diterimanya kepada LKS pada waktu yang telah disepakati oleh LKS dan nasabah.

- Bahwa agar akad tersebut sesuai dengan syariah Islam, DSN memandang perlu menetapkan fatwa tentang akad al-Qardh untuk dijadikan pedoman oleh LKS.

Akad transaksi qard merupakan akad transaksi yang mulia karena akad ini digunakan untuk menyalurkan dana bantuan sebagai pinjaman kepada orang lain yang sedang jatuh dalam kesulitan dengan kewajiban pengembalian hutang tepat pada waktu jatuh tempo dengan pertimbangan demikianlah maka DSN-MUI mengeluarkan fatwa sebagai peraturan dan pedoman untuk menjaga kedua belah pihak yang saling berhutang piutang tidak menimbulkan masalah konflik yang dapat merusak hubungan baik antara kedua belah pihak.

Berdasarkan pemaparan pertimbangan dan metode yang digunakan dalam menetapkan fatwa tentang akad transaksi syariah dapat disimpulkan bahwa Dewan syariah Nasional
MUI banyak mempertimbangkan kemaslahatan dan dampak yang akan terjadi ketika ditetapkanya dan tidak ditetapkanya fatwa oleh karena itu DSN MUI menetakan fatwa untuk memberikan kemaslahatan di masyarakat demi memnuhi kebutuhan masyarakat dalam bidang ekonomi agar masyarakat lebih meningkatkan usahanya mencapai kesejahteraan kemudian nantinya akan menurunkan angka kriminalitas yang disebabkan kemiskinan

\section{KESIMPULAN DAN SARAN}

Akad transaksi syariah merupakan bentuk kesepakatan dalam pengelolaan harta sehingga perlu diatur sedemikian rupa dengan membuat perarutan-peraturan tertentu untuk menjaga batasan-batasan terhadap akad transaksi agar supaya tidak keluar dari koridor syari'ah dan tidak berdampak kepada kerugian dan kedzaliman yang berkelanjutan dengan demikian paparan hasil penelitian terdahulu sudah jelas menggambarkan bahwa penetapan suatu hukum yang berkaitan dengan akad transaksi syariah memerlukan pertimbanganpertimbangan yang menyeluruh dengan melihat dari beberapa aspek diantaranya seperti, kondisi masyarakat, keadaan ekonomi global, dan kebutuhan masyarakat.

Kesimpulan yang dapat diambil dari pembahasan dan penelitian terdahulu mengungkapkan bahwa penetapan fatwa akad transaksi syariah dilakukan dengan melalui berbagai pertimbangan yang bertujuan untuk kemaslahatan umat dengan menggunakan konsep pendekatan dalam menentukan suatu hukum fatwa diantaranya yaitu konsep pendekatan nash qath'i dengan merujuk kepada al-qur ' an dan al-hadist yang sering digunakan oleh DSN-MUI dalam menetapkan fatwa diantara pertimbangan yang diambil DSN - MUI dalam menetapkan fatwa ialah menimbang manfaat dan dampak yang akan terjadi ketika ditetapkan atau tidak ditetapkan fatwa.

Sebagai saran untuk penelitian berikutnya diharapkan memberikan permasaalahan terbaru dimasa yang akan datang yang lebih komprehensif sehingga dapat memberikan manfaat yang lebih banyak dibidang ekonomi syariah demi terciptanya keamanan dan kenyamanan dalam hal bertransaksi.

\section{REFERENCES}

Arifin, D. (2014). Substansi Akad Dalam Transaksi Syariah.

Arto, M. (1998). Praktek Perkara Perdata pada Pengadilan Agama (Yogyakarta: Pustaka Pelajar).

Ascarya (2006). Akad dan Produk Perbankan Syariah: Konsep dan Praktek Di Beberapa Negara (Jakarta: Bank Indonesia).

Fauzi, N. A. (2017). Fatwa di Indonesia: Perubahan Sosial, Perkembangan dan Keberagamaan. Jurnal Hukum Novelty, 108-108.

Habibaty, D. M. (2017). Peranan Fatwa Dewa Syariah Nasional Majelis Ulama Indonesia Terhadap hukum Positif Indonesia. Jurnal Legislasi Indonesia, 447454.

id al Barawi, M. S. . (2009). Mazaliq al Fatwa (Kaherah: Dar al Basyir).

Jamal, B. A. (2016). Peranan Dewan Pengawas Syariah terhadap Praktik Kepatuhan Syariah dalam Perbankan Syariah di Indonesia. Jurnal Hukum IUS QUIA IUS TUM, 113-129.

Martunis (2017). Kedudukan Lembaga Fatwa (Studi Perbandingan Lembaga Fatwa

Dalam Hukum Islam dengan Komisi (Banda Aceh).

Shidiq, G. (2009).

Susamto, B. (2016). Tingkat Penggunaan Multi Akad Dalam Fatwa Dewan Syari Ah Nasional - Majelis Ulama Indonesia (DSN-MUI). Jurnal al-Ihkam. Yulianti, R. T. (2016)

Conflict of Interest Statement: The authors declare that the research was conducted in the absence of any commercial or financial relationships that could be construed as a potential conflict of interest.

Copyright (C) 2019 Ar Rasyid and Syamsul Bahri. This is an open-access article distributed under the terms of the Creative Commons Attribution License (CC BY). The use, distribution or reproduction in other forums is permitted, provided the original author(s) and the copyright owner(s) are credited and that the original publication in this journal is cited, in accordance with accepted academic practice. No use, distribution or reproduction is permitted which does not comply with these terms. 


\section{LIST OF TABLES}

$1 \quad$ Penelitian Terdahulu $\ldots \ldots \ldots \ldots \ldots \ldots$

2 Penetapan 11 Fatwa DSN-MUI 
TABLE 1 | Penelitian Terdahulu

\begin{tabular}{|c|c|c|c|}
\hline Nama & Penelitian & Tahun & Hasil \\
\hline Nur Hidayah & $\begin{array}{l}\text { Fatwa-fatwa dewan syariah nasional } \\
\text { atas aspek hukum islam perbankan } \\
\text { syariah di Indonesia }\end{array}$ & 2011 & $\begin{array}{l}\text { Di temukan penetapan fatwa menggunakan tiga } \\
\text { metode yaitu metode bayani, ta'lili, dan istishlahi } \\
\text { dengan mengungkapkan pertimbangan Dewan } \\
\text { Syariah Nasional MUI }\end{array}$ \\
\hline Rahmani Timorita Yulianti & $\begin{array}{l}\text { Pola ijtihad fatwa dewan syariah } \\
\text { nasional MUl tentang produk per- } \\
\text { bankan syari'ah }\end{array}$ & 2007 & $\begin{array}{l}\text { Di temukan metode sekaligus pertimbangan yang } \\
\text { banyak diambil Dewan Syariah Nasional Dalam } \\
\text { Menetapkan Fatwa }\end{array}$ \\
\hline
\end{tabular}


TABLE 2 | Penetapan 11 Fatwa DSN-MUI

\begin{tabular}{lll}
\hline No & Nama Akad & Nomor Fatwa \\
\hline 1 & Murabahah & 04/DSN-MUI/IV/2000 \\
2 & Salam & $05 / D S N-M U I / I V / 2000$ \\
3 & Istishna' & $06 /$ DSN-MUI/IV/2000 \\
4 & Mudharabah & $07 /$ DSN-MUI/IV/2000 \\
5 & Musyarakah & $08 / D S N-M U I / I V / 2000$ \\
6 & ljarah & $09 / D S N-M U I / I V / 2000$ \\
7 & Wakalah & $10 / D S N-M U I / I V / 2000$ \\
8 & Kafalah & $11 / D S N-M U I / I V / 2000$ \\
9 & Hawalah & $12 / D S N-M U I / I V / 2000$ \\
10 & Rahn & $25 / D S N-M U I / I V / 2000$ \\
11 & Qard & $19 / D S N-M U I / I V / 2000$ \\
\hline
\end{tabular}




\section{LIST OF FIGURES}

$1 \quad$ Konsep Metode . . . . . . . . . . . . . . . . . . . . . . . . . . . . 105 


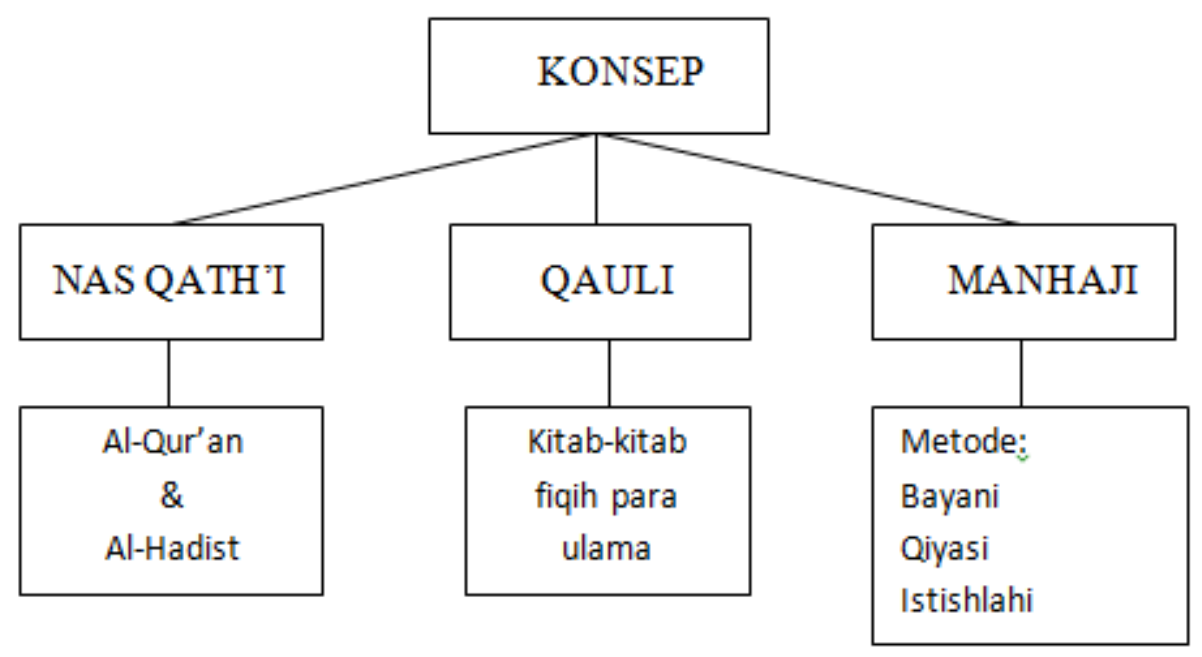

FIGURE 1 | Konsep Metode 